\title{
A Sociology of Appalachia: A Book Review Essay: Ramp Hollow: The Ordeal of Appalachia, by Steven Stoll
}

\section{Hill and Wang, 2017, 423 pages \\ ISBN: 9780809095056}

\section{Rosemary Gido \\ Professor Emerita \\ Indiana University of Pennsylvania \\ Editor, The Prison Journal \\ rgido@auxmail.iup.edu}

The 2016 presidential campaign and election of Donald Trump brought national 24hour news media outlets and "drive-by journalists" to West Virginia. Jobs in mining were disappearing and the aftereffects of the 2008 recession seemed as embedded here as a seam of bituminous coal. With Trump's pre-election promise to re-invigorate the Appalachian region's coal mining industry and his 42-point popular vote victory over Hillary Clinton, mainstream media added yet another "label" to the centuries-old stereotypes of Appalachia — "Trump Country."

Against this backdrop, J. D. Vance's 2016 book, Hillbilly Elegy, rose to the top of the New York Times best-seller list. A memoir, Vance's narrative re-introduced traditional "other America" depictions of Appalachian people and culture - 'out of time', poor, white, isolated, ethnically homogenous, welfare-dependent - and resurrected the 'culture of poverty' trope to explain the proliferation of poor life choices, substance abuse addiction, high unemployment, low education levels, and poor health habits passed down over generations by the people who reside there. ${ }^{1}$

In contrast, Steven Stoll's Ramp Hollow: The Ordeal of Appalachia, published in November, 2017, is an historian's carefully researched and documented history of the dispossession of the self-sufficient West Virginian white agrarian class, with West Virginia standing for an exemplary of Appalachia as a whole. Shifting the focus from one of intransigence to one centered on power and the steady erosion of an $18^{\text {th }}$ and $19^{\text {th }}$ century way of life by the external forces of industrial capitalism, Stoll systematically weaves together a socio-economic analysis of the structural origins and persistence of poverty.

This essay summarizes the major themes of Ramp Hollow, and supplements the review with a discussion of complementary historical and sociological studies of Appalachia over the last 50 years. 


\section{The Resource Curse of Appalachia: Land and Dispossession ${ }^{2}$}

One can easily compare the geophysical and geopolitical problems of Stoll's central Appalachia to other US regions and states where environmental resources have been used and abused as timber logging and mining for coal and gas have ebbed and flowed (Diamond, 2005; Dublin \& Light, 2005; Wyckoff \& Dilsaver, 1995). For Stoll, the starting point of his research is simple and direct - "how people get kicked off land and why we don't talk about them." (p. xiv).

The missing piece for Stoll is a 400-year history of land and dispossession in Appalachia. While acknowledging the dispossession of Native Americans here and across Appalachia (pp. 24-28; 179-183) and of African American farmers during Reconstruction (pp. 185-189), Stoll focuses on the early white Swede and Scots-Irish settler pioneers who farm, raise livestock, hunt, and draw on other forest resources in the difficult mountainous environment. Avoiding elevating these early Jeffersonian pioneer farmers to a 'noble status,' historian Stoll draws analogies of their challenging agrarian livelihood to English peasants and Philippine rice growers and the eventual imposition of enclosure. He ruminates that they are actors out of a 10,000-year history of agrarian selfsufficiency - ones that "we have lost the language to describe."3

Following the French \& Indian War and the American Revolution, the conversion of land in the western Virginia wilderness to land property ownership was largely governed by the Commonwealth of Virginia. George Washington first received a "warrant for five thousand acres in the undulating plateau between the rivers Kanawha and Ohio" in 1763, a military service reward from the royal governor of Virginia (p. 101). Washington would later have the land surveyed in 1774 and visit it in 1784, finding he would have to deal with a sect of squatting Presbyterians who, after a trial, were evicted. Similar to Washington, absentee landlords scooped up 93\% of western Virginia between 1780 and 1810. Settlers on the land occupied 7\% or 324,000 acres (pp. 101104), but the definition of possession or lack thereof would be the basis for West Virginia's mass dispossession movement, particularly following the Civil War.

For Stoll, the freedom of these self-sufficient agrarians would cease when they stopped growing their food. Before West Virginia statehood and the arrival of railroad and banking interests, family households wrote their own settler deeds for their land holdings, and more typically they "moved onto land regardless of who owned it" (p. 102). Further, they supplemented their holdings through the shared usage of forest "commons" for hunting and critical food foraging, similar to $16^{\text {th }}$ century English peasants. Importantly, "they sustained themselves, exchanged what they wanted, when 
they wanted, not because they needed it for survival." (p. 44). Indeed, these "smallholders" fought back when challenges to this livelihood first exposed their political vulnerability during the Whiskey Rebellion.

Stoll devotes an entire chapter (Chapter 3: The Rye Rebellion: Why Alexander Hamilton Invaded the Mountains) on the new Federalist Party government Secretary of the Treasury, Alexander Hamilton, and his efforts to impose a tax on rye that Appalachian farmers produced to trade for provisions the "homeplace" did not provide-one of the few times cash as capital was used in their economy. Yet, here was Hamilton envisioning the new nation state as a governing economy, and the 1791 Whiskey Tax was part of his larger strategy to turn all labor into money and get rid of the outmoded system of barter. As the Whiskey Rebellion, which took place in four western Pennsylvania counties, is best remembered for local administrations of tar and feathers and whippings to tax collectors and the massive deployment of 13,000 Hamilton-led militia to face 500 insurgents (who disappeared and did not show up for battle). Stoll declares the highlanders victorious. With the 1800 election of the Republican president, Thomas Jefferson, the Whiskey Tax is repealed (pp. 93-124). Nonetheless, Indian wars, debt, challenges to their land ownership, and the call of the frontier would encourage some of the tenants to flee, leaving behind the rest to face the next 100 years of industrial invasions and the pressures to sell their labor as external powers enclosed their landscapes.

\section{Enclosure}

Stoll characterizes the initiation of West Virginia statehood and the post-Civil War era as a scramble for Appalachia — not for the land but for its rich ecological resources in wood and coal that created a manic outbreak of speculative competition. Data provided a base for the enterprises, with newly-produced geological and geographical maps of coal a stimuli for capital invasion - in particular an 1848 map of West Virginia's coal deposits, part of the 3-state Allegheny Bituminous Coal Field. Where coal was lacking, the mountains provided a plentiful source of trees for wood, and commercial logging began in the 1870's. (pp. 128-131). It is the cutting of the woods that Stoll declares the beginning of enclosure, as the capitalists came with the railroads to 'dismantle the ecological base" (p.132). He discusses in great detail the major forces that reduced these households from ones of agency to ones of dependency and which paved the road to enclosure:

Population pressures: A high agrarian family birth rate increased the mouths that needed to be fed and the number of farms that households divided from their land holdings to kin. 
Commodity value deterioration: Particularly from 1840-1880, the quantity and value of corn, potatoes, cattle and pigs dropped. Store merchants did set up accounts and accept promissory notes from a class still dominated by a barter economy. (Stoll further acknowledges that these farmers had not, for the most part, changed their farming method technologies, another factor accounting for losses),

Loss of homeplace: The jumbled nature of property claims were the main venue for loss of longtime inhabitant acres, as outlined below.

Ecological destruction: The total destruction of the forest of West Virginia took about 50 years. During the 1880 s, powered-by-coal steam skidders hacked away at the trees, pulling the logs onto a flatbed railroad car - "of the 10 million acres that had never been cut in 1870, only 1.5 million stood in 1910" (p. 169).

Stoll outlines the major political players who become capitalism's partners. Again, he asks a direct question: "What made politicians think they could do whatever they wanted wherever they wanted?" (p. 136). Echoing contemporary "pay for play" schemes and the creation of corporate lobbies, late $19^{\text {th }}$ century West Virginia politicians at the state and federal level actively engaged oil magnates and railroad, timber, and coal barons in drafting legislation for their benefit. The state legislature overrode county governments through the creation of judicial systems sympathetic to industrialists, and after 1890 , their judges were no longer upholding settler deeds. ${ }^{4}$

With agrarian sustenance waning and the disappearance of the "commons", farmers were drawn to wage work in logging camps, most with the hope of using the new cash economy as a vehicle for returning to their traditional way of earning a living. Coal companies swindled farmers with dubious land titles by buying mineral rights to their land. This new type of dispossession brought only one alternative for these households-moving to company work camps, with dependence on paid scrip and tenancy in substandard housing that lasted through the 1960s. Like the $16^{\text {th }}$ century English peasants whose common lands were taken over as private property by the aristocracy, the Appalachian agrarian enclosure was complete.

Throughout the book, Stoll provides examples, from early travel writers' narratives and missionaries' accounts, to social scientists' environmental and biological determinism theories into the $20^{\text {th }}$ century - evolving stereotypical images and metaphors of the people of the mountains and hollows as isolated "hillbillies", racially apart, and often impervious to the elevated life changes offered by capitalism (Fraley, 2011). These representations of West Virginia and all of Appalachia as a "place needing to be fixed" 
have become firmly lodged in public and policy narratives ( So, 2014;Hanna, 2000). The remainder of this essay provides highlights from the last 50 years of sociological and historical research that have created alternative models to displace the rigid cultural dependency imagery of Appalachia.

\section{The War on Poverty: Appalachia as a Colony Model}

Sociologists who read Ramp Hollow will be reminded of the emergent Appalachian Studies scholars of the1960s--critical sociologists and historians who responded to the culture of poverty discourse and policy debates generated by the War on Poverty, and challenged its model for once again attributing the problems of the region to the deficiencies of its people and culture. Like Stoll, drawing on the history of the region's decapitalization and environmental exploitation, Karen Matthews Lewis and her associates offered a model of Appalachia as an internal colony, a conceptual lens and paradigm for viewing and understanding the region's centuries' long economic plundering and political control by outsiders. The essays by Karen Lewis and academic and non-academic writers in Colonialism in Modern America (1978) add sociological depth to Stoll's historical narrative. They provide insight into active adaptations by the family and the church to the process of internal colonization, which were analogized to other societies under colonial domination. Miners, Millhands, and Mountaineers: Industrialization of the Appalachian South, 1880-1930 (1982) by Ronald Eller, an Appalachian historian and activist of this 'school,' extends Stoll's earlier regional history of the timber industry through 1930, with details of the transformation from household self-sufficiency to dependency on outside corporate control. Notably, Appalachia on our Mind (1978) by Henry D. Shapiro, a contemporary intellectual historian from the University of Cincinnati, was a significant scholarly contribution to the "sociology of Appalachia", delineating how the stereotypes of cultural determinism were created over time by the actors that Stoll discusses (See also: Werner, Billings \& Blee, 2010; Billings, et al, 1999). John Gaventa's Power and Powerlessness (1980) was one of the earliest case studies of Appalachian community activism against coal company power and control.

\section{The Regional Development Model}

As culture as a cause of poverty became the linchpin of the Kennedy and Johnson administrations, several popular books of the day were credited with shaping the public narrative. JFK is said to have read The Other America: Poverty in the United States (Harrington, 1963) days before his death. It is the anthropologist, Oscar Lewis, however, who is recognized for the 'invention' of the culture of poverty concept for understanding a culture's normative and adaptive solutions to societal challenges - and which explained the intergenerational perpetuation of poverty (Lewis, 1959). With President Johnson's 
declaration of the War on Poverty and the passage of the 1965 Appalachian Regional Development Act, the culture of poverty concept became intertwined with existing views of the 'undeserving poor,' black family structural disorganization (Moynihan, 1965), and its designation as the primary cause of welfare dependency. Harry M. Caudill's Night Comes to the Cumberlands: A Biography of a Depressed Area (1962) about Eastern Kentucky's coal country, is also cited as fueling the political and policy dialogue that would result in the creation of the Appalachian Regional Commission (ARC). A lawyer and activist, Caudill lobbied for Eastern Kentucky worker training and regional economic enterprises to move away from coal dependence. ${ }^{5}$

In the 54 years since its creation, the Appalachia Regional Commission can be categorized as one of the first federal efforts to apply a regional development model as a strategic economic policy tool to address poverty. From the beginning, Appalachian regional development advocates were academics based in sociology, economics and agricultural economics from West Virginia University, the University of Kentucky and the University of Tennessee (Walls, 1978). At the 50 th anniversary of ARC's founding, economic intervention benefits and deficiencies were again reviewed (Center for Regional Economic Competiveness and West Virginia University, 2015; Isserman, 1997). Using the same economic indicators utilized in the 1964 ARC report (Center for Regional Economic Competiveness and West Virginia University, 2015, p.5), there was:

*Continued income disparity between Appalachia and the rest of the US;

* Relatively high unemployment, decline in employment and worker and resident out-migration from the region

*Over-concentration of employment in extractive industries

*Low educational attainment, poor housing, and poor health

*Relative isolation -lack of transportation access and limited communications

Appalachian scholars have continued to challenge this federal and state development infrastructure model and its foundation in cultural misconceptions. Ronald Eller has summarized the emergence of Appalachian grassroots and community activism, scholarship, and the transformation of the region's economy from rural manufacturing to the service sector in the 1980s and 1990s in Uneven Ground: Appalachia since 1945 (Barksdale, 2009).

\section{Agency and Social Capital Model}

In the final chapter of Ramp Hollow, Steven Stoll steps away from his role as historian and offers a proposal for social action intervention to address Appalachia's continued socio-economic challenges. ${ }^{6}$ He outlines a "Commons Communities Act", 
legislation that would bring back land for shared use by families in what seems like an effort to return to the 'old ways' of farming and gardening, hunting, raising cattle, etc. in Appalachia and across other rural and even urban locales. The common communities' social and educational services supports will come from an income tax on the top $1 \%$ of US taxpayers, with a variety of other low-income tax incentives for residents and key players like teachers and medical doctors. Free college tuition, enhanced internet connectivity, and agricultural experimental stations round out the model which returns the spirit of individual power and entrepreneurship (pp. 272-275).

One can readily ask what Stoll must be thinking? As yet another set of Appalachian stereotypes and depressing statistics fill the airwaves and medical research studies-The Opioid Epidemic and its linkage to poverty, unemployment, and disability can now be "mapped" across Appalachia (Appalachian Regional Commission, March, 2018) and correlated with county mortality rates and voting patterns for Donald Trump (Monnat, December 14, 2016). Stoll's only justification is that "we need to know history in order to make policy" (p. 289).

\section{Endnotes}

${ }^{1}$ Elizabeth Catte, a public historian from Eastern Tennessee, has attacked J. D. Vance's Hillbilly Elegy depictions in her book, What you are getting wrong about Appalachia (2018), Belt Press. See S. Jones (February 6, 2018). The truth about Appalachia http://new republic.com/article/146959/truth-appalachia.

${ }^{2}$ Griswold, E (June 9, 2018). The resource curse of Appalachia. https://www.nytimes.com/2018/06/09/opinion/sunday/appalachia-environment-resourcecurse.html.

${ }^{3}$ Steven Stoll as part of an author panel discussion, March 24, 2018, Virginia Festival of the Book, Charlottesville, VA. https://www.c-span.org/video/?442664-2/authordiscussion-appalachia.

${ }^{4}$ Stoll profiles Johnson Camden, elected to the US Senate in 1881, whose oil company became part of J.D. Rockefeller's Standard Oil in 1875. As senator, he created a consortium to fund a railroad for Standard oil delivery and acted as a lobbyist for his own company (p. 138). Similarly, William MacCorkle, elected governor in 1892, would boast of "advertisements of the state to the great national constructive interests." (p. 140)

${ }^{5}$ Harry Caudill in later years would become discouraged in failing to attract government resources for his ideas for rejuvenating Eastern Kentucky. He would become a full- 
fledged follower of William Shockley's school of eugenics, and place the blame for social ills on "genetic decline." See Cheves, J. and B. Estep (November 12, 2015). Chapter 4: Disillusioned, Harry Caudill blames 'genetic decline' in Eastern Kentucky. http://www.kentucky.com/news/special-reports/fifty-years-ofnight/article44394057.html.

${ }^{6}$ The latest ARC Appalachian "Income and Poverty Data Snapshot" shows household income is $80 \%$ of the US average, and the poverty rate, at $16.7 \%$, compared to the US average of $15.1 \%$.(https://www.arc.gov/appalachian_region/FactSheets.asp.). West Virginia remains one of the 6 U.S. states most dependent on oil, gas, and coal productivity (B. Plumer (August 8, 2014). https://www.vox.com/xpress/2014/8/8/5982865/these-6-states-are-most-dependent-onoil-gas-and-coal-production. West Virginia University is again attempting to identify development opportunities across the state in a new program, West Virginia Forward. See D. Mazzella (Spring, 2018) "How to remake a state." West Virginia Magazine, pp. 34-39.

\section{References}

Appalachian Regional Commission (March 2018). New data visualization tool enables in-depth, county-by-county look at impact of opioid epidemic in Appalachian region. Retrieved July 28, 2018: https://www.arc.gov/news/article.asp?ARTICLE_ID=622.

Barksdale, K. (March, 2009). Barksdale on Eller, 'Uneven ground: Appalachia since 1945' (Review). Retrieved August 2, 2018: https://networks.h-net.org/node/2713/ reviews/3847/barksdale-eller-uneven-ground-appalachia-1945.

Billings, D. \& Blee, K. (2004). Social origins of Appalachian poverty: Markets, cultural strategies and the state in an Appalachian Kentucky community, 1804-1940. Rethinking Marxism, 16, pp. 19-36. https://doi.org/10.1080/0893569042000193380

Billings, D., Gurney, N., \& Ledford, K. (1999), Eds. Back Talkfrom Appalachia: Confronting stereotypes. Lexington, KY: University of Kentucky Press.

Caudill, H.M. (1963). Night comes to the Cumberlands: A biography of a depressed area. New York, NY: Brown, Little, \& Brown.

Diamond, J. (2005). Collapse: How societies choose to fail or succeed. New York: Penguin Books. See Chapter 1: Under Montana's Big Sky. 
Dublin, T. \& Light, W. (2005). The face of decline: The Pennsylvania anthracite region in the $20^{\text {th }}$ century. Ithaca, NY: Cornell University Press.

Duncan, C. M. (1999). Worlds apart: Why poverty persists in America. New Haven, CT: Yale University Press.

Eller, R.D. (1982). Miners, Millhands, and Mountaineers: Industrialization in the Mountain South, 1880-1930. Knoxville, TN: University of Tennessee Press.

Eller, R. D. (2008). Uneven Ground: Appalachia since 1945. Lexington, KY: University of Kentucky Press. https://doi.org/10.5810/kentucky/9780813125237.001.0001

Fraley, J. (2011). Missionaries to the wilderness: A history of land, identity, and moral geography in Appalachia. Journal of Appalachian Studies, 17, pp. 28-41.

Gaventa, J. (1980). Power and powerlessness: Quiescence and rebellion in an Appalachian valley. Chicago, IL: University of Illinois Press.

Hanna, S. (2000). Representation and the reproduction of Appalachian space: A history of contested signs and meanings. Historical Geography, 28, pp. 179-207.

Harrington, M. (1963). The other America: Poverty in the United States. Baltimore, MD: Penguin Books.

Isenberg, N. (2016). White trash: The 400-year untold history of class in America. New York, NY: Viking.

Isserman, A. M. (1997). Appalachia then and now: An update of "The realities of deprivation" reported to the president in 1964. Journal of Appalachian Studies, 3, pp. 43-69.

Lewis, H. M., L. Johnson, and D. Askins, Eds. (1978). Colonialism in America. Boone, NC: Appalachian Consortium Press.

Lewis, O. (1959). Five families: Mexican case studies in the culture of poverty. New York: Basic Books.

Monnat, S. M. (December 4, 2016). Deaths and despair and support for Trump in the 2016 presidential election. University Park, PA: The Pennsylvania State University Department of Agricultural Economics, Sociology, and Education 
Research Brief, pp. 1-9.

Moynihan, D. P. (1965). The Negro family: The case for national action. Washington, DC: Office of Policy Planning and Research, US Department of Labor.

Shapiro, H. D. (1978). Appalachia on our mind: The southern mountains and mountaineers in the American consciousness, 1870-1920. Chapel Hill, NC: University of North Carolina Press.

So, G. From "pockets of poverty" to potential prosperity in Appalachia: Examining mass media narratives of poverty stereotypes in Appalachia. The Elton Journal of Undergraduate Research in Communications, 5, pp. 71-88.

Suh, S. and K. Heise (2014). Re-evaluating the "culture of poverty." Retrieved June 20, 2018 from The Society - https://thesocietypages.org/roundtable/culture-ofpoverty/.

Vance, J. D. (2016). Hillbilly elegy: A memoir of a family and culture in crisis. New York, NY: Harper and Row.

Walls, D. (1978) Internal colony or internal periphery: A critique of current models and and alterative formulation in Lewis, H.M., et al, Eds. (1978). Colonialism in America, pp. 319-350. Boone, NC: Appalachian Consortium Press. https://doi.org/10.2307/j.ctt1xp3n1t.28

West Virginia Center for Regional Competitiveness and West Virginia University (February, 2015). Appalachia then and now. Retrieved June 16, 2018http://arc50.creconline.org/

Wyckoff, W. and L. M. Dilsaver (1995). The mountainous west: Explorations in historical geography. Lincoln, NE: University of Nebraska. 